\title{
Twenty Interesting Points: An Analysis of Bone Artefacts from Platypus Rockshelter
}

\author{
Victoria Francis \\ Archaeological Sciences Laboratory, School of Social Science, University of Queensland, \\ Brisbane, Queensland, 4072, Australia
}

\begin{abstract}
While bone artefacts have been largely ignored in Australian archaeology, a wide range of functions for this artefact type are noted ethnographically. Twenty bone artefacts from Platypus Rockshelter, southeast Queensland, were used to test the applicability of residue analysis for functional assessment of archaeological bone artefacts. Analysis produced both predicted and unexpected results when compared with the known range of functions and results from other studies at this site. Plant and animal residues were observed on the artefacts, ranging from blood and collagen to starch raphides and the mineral, vivianite. These results have implications for site occupation as well as more general ones for the study of bone artefacts.
\end{abstract}

\begin{abstract}
Introduction
Few scientific studies have been conducted on Australian Aboriginal bone points despite their being found in archaeological deposits throughout Australia dating well into the Pleistocene, the oldest specimens coming from Devil's Lair dated to 29,000 BP (Flood 1990). Although a wide range of sizes, shapes and functions is recorded ethnographically for this artefact type, it is common for archaeologists to infer that their presence in sites is evidence of either skin-working or fishing activities (e.g. Beaton 1977; Bowdler 1970, 1979; Flood 1974, 1980, 1990, 1995; Lampert 1971; McBryde 1974; Pretty 1977). The relative paucity of bone artefact studies in Australia is probably due largely to their fragility. Further, analytical techniques such as scanning electron microscopy (commonly used elsewhere) can considerably damage bone artefacts (Fisher 1995; LeMoine 1994; Olsen 1988). Although attempts at residue and use-wear analysis have been made on Australian specimens (e.g. Webb 1987; Webb and Allen 1990), the residue results are downplayed in favour of the apparently more conclusive use-wear results. In the study reported here, residue analysis of bone artefacts from Platypus Rockshelter, southeast Queensland, was undertaken to evaluate whether or not archaeological bone points were used for functions described ethnographically.
\end{abstract}

\section{Ethnographically Recorded Functions of Bone Artefacts}

Ethnographies that recorded Aborigines at the closest possible point of contact with Europeans were reviewed in order to ascertain a functional range for Australian bone artefacts. As Table 1 outlines, bone point functions ranged from food-procuring utensils (fishhooks, spears) to ornaments (nose-bones, cloak toggles, ear piercing, hair pins) and weapons (death spears, strangling cords, death bones, bone pins).

While a diverse range of functions for bone artefacts has been recorded in Australia, these are most frequently associated with skin working (sewing, pegging out skins, smoothing seams, awls - e.g. McCarthy 1976) and fishing activities (i.e. fishhooks and fishing spear barbs - see Massola 1957). Their use throughout Australia as nose ornaments is also relatively well documented (see McCarthy 1976).

\section{Platypus Rockshelter}

Platypus Rockshelter is a weathered double-chambered cavern in a Mesozoic conglomerate outcrop overlooking the Brisbane River some $60 \mathrm{~km}$ west of Brisbane (Figure 1). Excavated as a salvage operation in the late 1970s, it has been covered by the waters of Wivenhoe Dam since 1985 (Hall 1980; Hall et al. 1988). Excavation recovered thousands of stone artefacts associated with large amounts of bone and shellfish (predominantly freshwater mussel) (Hall et al. 1988). Various studies have been conducted at the site including detailed analyses of chronology, stratification and site formation (Hall et al. 1988), a taphonomic assessment of the faunal assemblage (Novello 1989), a technical analysis of the stone artefact assemblage (Hiscock and Hall 1988) and a lithic residue analysis (Skelton 1996). Site occupation, spanning a period between $560 \pm 60$ BP (Beta-3076) and 4,540 \pm 80 BP (Beta-3074), was generally sporadic and was influenced by the changing morphology of the rockshelter (Hall et al. 1988). Owing to the site's proximity to permanent water, it is considered to have been used by larger groups mainly during winter months (Lilley 1978).

The faunal assemblage exhibited a wide taxonomic range including mammals, birds, reptiles, amphibians and fish. As numerous anthropogenic bones have been identified in that assemblage (Novello 1989), the lithic assemblage was also expected to exhibit evidence of meat processing. Surprisingly, residue analysis of stone artefacts revealed a predominance of plant material (starch, raphides and cellulose), with only one artefact yielding animal residue (Skelton 1996). While this sole blood specimen was identified as mammalian, the more abundant plant residues could not be taxonomically resolved.

\section{The Bone Artefact Assemblage}

Twenty bone artefacts were recovered from the Platypus Rockshelter deposits. They were distributed both horizontally and vertically throughout the excavated deposits, several being found lying on the various 'living floors' identified during excavation. As shown in Figure 2, this assemblage comprises two bi-pointed artefacts (Artefacts 2-3), one uni-pointed artefact (Artefact 1, the shape of which was similar to ethnographically collected and observed awls) and 17 pointed/chipped bone shaft fragments (Artefacts 4-20). 
Table 1. An overview of Australian bone point function.

\begin{tabular}{|c|c|c|c|c|}
\hline Food Procurement & Ornamental & Weaponry & $\begin{array}{l}\text { Manufacturing } \\
\text { Equipment }\end{array}$ & Other \\
\hline $\begin{array}{l}\text { Fishhooks (Smyth } \\
\text { 1878; Spencer 1904; } \\
\text { Thomson 1936) }\end{array}$ & $\begin{array}{l}\text { Nose bones (Angas } \\
\text { 1969[1847]; Dawson } \\
\text { 1881; Kenyon 1912; } \\
\text { Roth 1984[1897- } \\
\text { 1910) }\end{array}$ & $\begin{array}{l}\text { Death spears } \\
\text { (Flanagan 1888) }\end{array}$ & $\begin{array}{l}\text { Needles (Curr 1883; } \\
\text { Dawson 1881; Petrie } \\
\text { 1904; Spencer 1915; } \\
\text { Worsnop 1897) }\end{array}$ & $\begin{array}{l}\text { Canoe punter (Roth } \\
\text { 1984[1897-1910]; } \\
\text { Worsnop 1897) }\end{array}$ \\
\hline $\begin{array}{l}\text { Extracting shellfish } \\
\text { (Kenyon 1912; } \\
\text { Spencer 1915) }\end{array}$ & $\begin{array}{l}\text { Cloak toggles } \\
\text { (Dawson 1881; Smyth } \\
\text { 1878) }\end{array}$ & $\begin{array}{l}\text { Strangling cords } \\
\text { (Smyth 1878) }\end{array}$ & $\begin{array}{l}\text { Awls (for skin and } \\
\text { plant material) (Smyth } \\
\text { 1878; Roth } \\
1984[1897-1910])\end{array}$ & $\begin{array}{l}\text { Digging stick (Le } \\
\text { Souef } 1916 \text { cited in } \\
\text { Webb 1987) }\end{array}$ \\
\hline $\begin{array}{l}\text { Eel/fish spears (Curr } \\
\text { 1886; Dawson 1881; } \\
\text { Spencer 1915; } \\
\text { Thomson 1936) }\end{array}$ & $\begin{array}{l}\text { Gum lancing (Collins } \\
\text { 1910) }\end{array}$ & $\begin{array}{l}\text { Death bones (Roth } \\
\text { 1897; Smyth 1878; } \\
\text { Thomson 1936) }\end{array}$ & $\begin{array}{l}\text { Bark piercing (Roth } \\
\text { 1984[1897-1910]; } \\
\text { Thomson 1936) }\end{array}$ & \\
\hline $\begin{array}{l}\text { Spear thrower rest } \\
\text { (Spencer 1915) }\end{array}$ & $\begin{array}{l}\text { Ear piercing (Roth } \\
1984[1897-1910])\end{array}$ & Bone pins (Roth 1897) & $\begin{array}{l}\text { Smoothing seams } \\
\text { (Smyth 1878) }\end{array}$ & \\
\hline \multirow[t]{2}{*}{$\begin{array}{l}\text { Picking kernels from } \\
\text { nuts (Roth 1984[1897- } \\
\text { 1910]) }\end{array}$} & $\begin{array}{l}\text { Incising skin (Smyth } \\
1878 \text { ) }\end{array}$ & & $\begin{array}{l}\text { Wood chisel (Curr } \\
\text { 1886; Dawson 1881; } \\
\text { Spencer 1915; } \\
\text { Thomson 1936) }\end{array}$ & \\
\hline & Hair pin (Curr 1883) & & $\begin{array}{l}\text { Stone tool fabricator } \\
\text { (Mitchell 1949) }\end{array}$ & \\
\hline
\end{tabular}

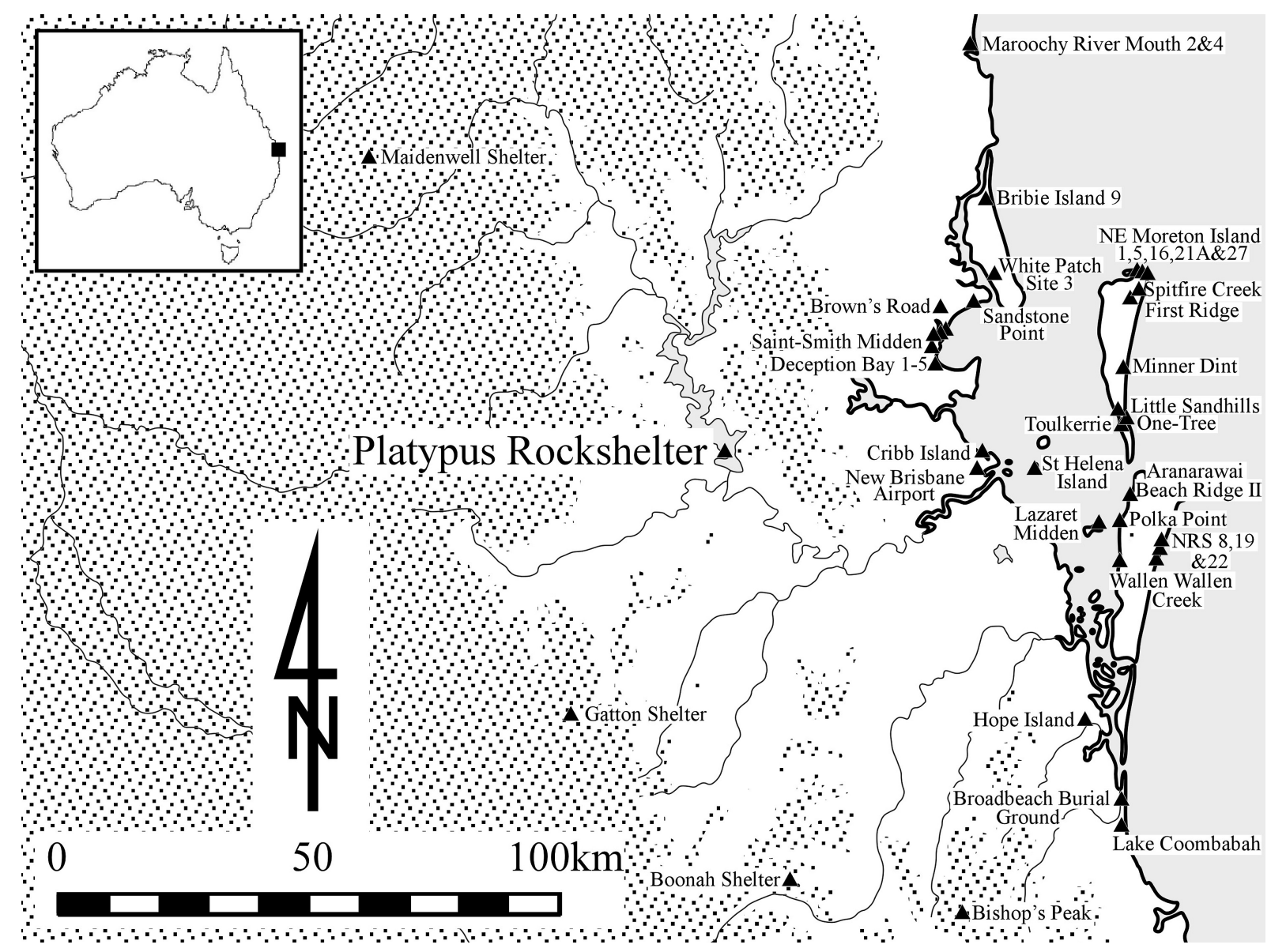

Figure 1. Map of dated archaeological sites in southeast Queensland, highlighting the location of Platypus Rockshelter (after UIm and Hall 1996:47). 


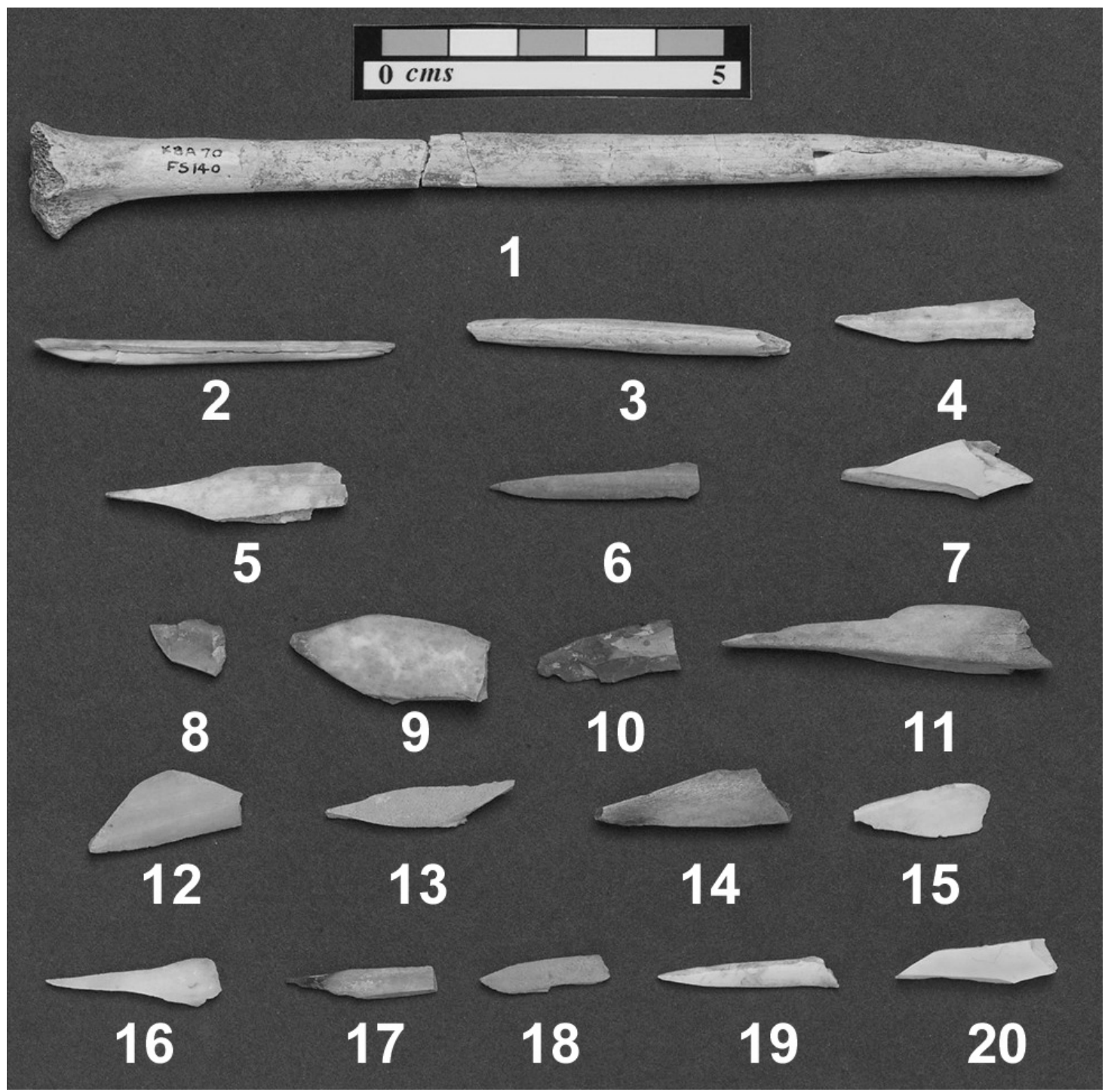

Figure 2. The Platypus Rockshelter bone artefact assemblage (Photograph: Information Technology Services Unit, University of Queensland).

\section{Methods}

Residue analysis incorporates methods from a range of fields including histology, forensics, botany and immunology (Loy 1999) and is based on the key forensic premise that contact between two materials inevitably causes some matter transfer (Loy 1993, 1994; Loy et al. 1992). Another key premise is that organic material can remain preserved indefinitely on artefacts under a wide range of environmental conditions.

Microscopy is the one crucial method that must be conducted to locate and identify residues, providing particular diagnostic features are present and particular effects are achieved using different types of illumination. For example, plant residues can be distinguished from animal residues by their differential reaction to crosspolarised light (Loy 1999). Other tests may be conducted on residues to chemically identify (Hemastix ${ }^{\circledR}$ and $\mathrm{Na}$ EDTA tests for haemoglobin) and categorise residues (e.g. Staphylococcal A to identify whether or not blood is mammalian) (Loy 1999).

This study was conducted solely through the use of microscopy to detect and identify residues on the artefact surfaces (BX60 Olympus microscope at magnifications of $\mathrm{x} 50, \mathrm{x} 100, \mathrm{x} 200, \mathrm{x} 500$ and $\mathrm{x} 1000)$. This single method was used so as to cause the least damage to the artefacts and to prevent destruction of the residues. Bright field (BF) and dark field (DF) incident lighting was employed in order to observe features on artefacts. Dark field lighting provides more contrast between the surface features due to the placement of a stopper over the light source that diminishes the amount of light projected onto the microscope stage (Loy 1999, in prep.). Bright field lighting is more useful for observing use-wear or manufacturing marks as there is less contrast. However, bright field lighting can be used with cross-polarised (XPOL) lighting to observe how much light a residue refracts; this can help distinguish between plant (e.g. starch, raphides, cellulose) and collagen or keratin residues (Loy in prep.).

\section{Results}

A range of residues was observed on the artefacts and they were classified as plant, animal or inorganic (Table 2). The most remarkable of the animal and plant residues are discussed below. 
Table 2. Summary of the residues observed on the Platypus Rockshelter bone artefact assemblage. Numbers in brackets indicate the original artefact specimen code. $\mathrm{SU}=$ stratigraphic unit.

\begin{tabular}{|c|c|c|c|c|}
\hline Artefact ID & SU & Plant Residues & Animal Residues & Inorganic Residues \\
\hline $1(140)$ & VIIa & none & collagen and lipids & none \\
\hline $2(127)$ & VI & none & lipids and keratin & none \\
\hline $3(120 / 2)$ & IV & cellulose, starch & lipids & none \\
\hline $4(226 / 3)$ & $\mathrm{V}$ & $\begin{array}{l}\text { starch, raphides, crystalline plant } \\
\text { residue }\end{array}$ & none & none \\
\hline $5(226 / 2)$ & V & $\begin{array}{l}\text { cellulose, starch, bordered pits } \\
\text { associated with a clear smooth } \\
\text { residue }\end{array}$ & none & none \\
\hline $6(23 / 7 b)$ & I & starch, plant material & none & none \\
\hline $7(120 / 6 f)$ & IV & resin, charcoal fragments & lipids & ochre fragments \\
\hline $8(161)$ & VI & $\begin{array}{l}\text { starch, resin, crystalline plant } \\
\text { material }\end{array}$ & none & none \\
\hline $9(124 c / 4 b)$ & VI & $\begin{array}{l}\text { crystalline material associated } \\
\text { with raphides, starch }\end{array}$ & none & none \\
\hline $10(122 / 10)$ & $\mathrm{V}$ & $\begin{array}{l}\text { charcoal, crystalline residue } \& \\
\text { cellulose, starch }\end{array}$ & none & none \\
\hline $11(79-23 / 7 b)$ & VIIa & crystalline residue & none & large amounts of ochre \\
\hline $12(117 / 6 a)$ & II & $\begin{array}{l}\text { crystalline residue associated } \\
\text { with starch, raphides, cellulose \& } \\
\text { plant cell walls }\end{array}$ & none & none \\
\hline $13(82 / 2 b)$ & VI & $\begin{array}{l}\text { crystalline residue associated } \\
\text { with starch \& cellulose }\end{array}$ & none & none \\
\hline $14(197 / 10)$ & $\mathrm{V}$ & $\begin{array}{l}\text { relatively large amounts of clear } \\
\text { smooth residue }\end{array}$ & none & none \\
\hline $15(120 / 6 \mathrm{e})$ & IV & none & none & synthetic fibre \\
\hline $16(113 / 6 \mathrm{e})$ & VIIa & $\begin{array}{l}\text { crystalline residue associated } \\
\text { with starch, raphides, cellulose \& } \\
\text { plant cell walls }\end{array}$ & none & none \\
\hline $17(23 b-31 / 7 a)$ & I & $\begin{array}{l}\text { crystalline residue associated } \\
\text { with starch, raphides, cellulose \& } \\
\text { plant cell walls }\end{array}$ & none & none \\
\hline $18(113 / 6 d)$ & VIIa & $\begin{array}{l}\text { smooth clear residue, crystalline } \\
\text { residue associated with starch } \\
\text { grains }\end{array}$ & none & none \\
\hline $19(150 / 15 b)$ & IV & $\begin{array}{l}\text { bordered pits associated with } \\
\text { clear residue, starch grains }\end{array}$ & none & none \\
\hline $20(33 / 13 f)$ & II & none & $\begin{array}{l}\text { lipids, collagen, } \\
\text { blood residue }\end{array}$ & ink \\
\hline
\end{tabular}




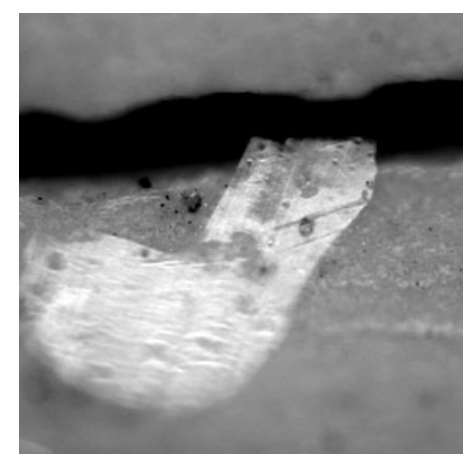

Figure 3. Keratin fragment from Artefact 2, DFX100 (Photograph: V. Francis).

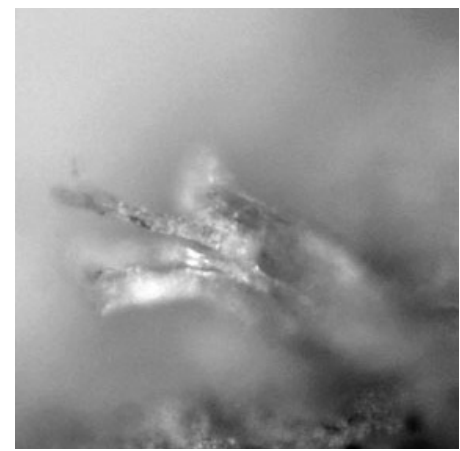

Figure 5. Entwined collagen fibres from near the tip of Artefact 1, BFXPOLX500 (Photograph: V. Francis).

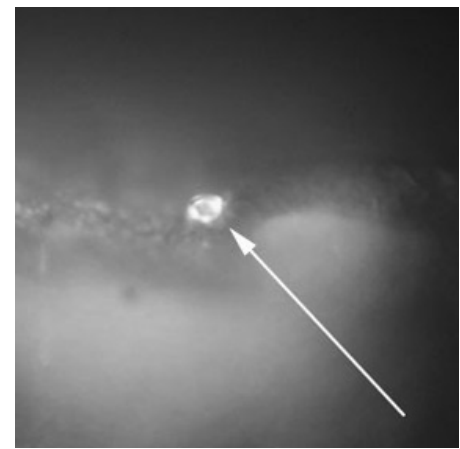

Figure 7. Bordered pit from Artefact 5, BFXPOLX1000 (Photograph: V. Francis).

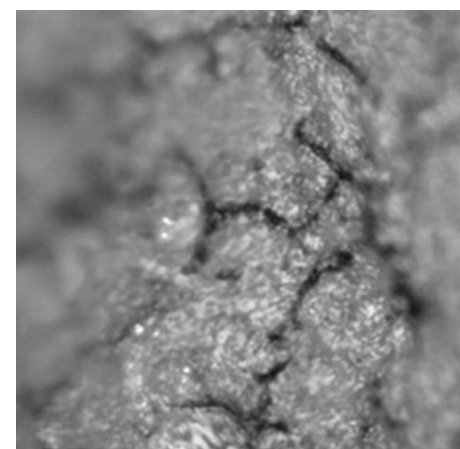

Figure 9. Dried resin near surface of Artefact 8, DFX500 (Photograph: V. Francis).

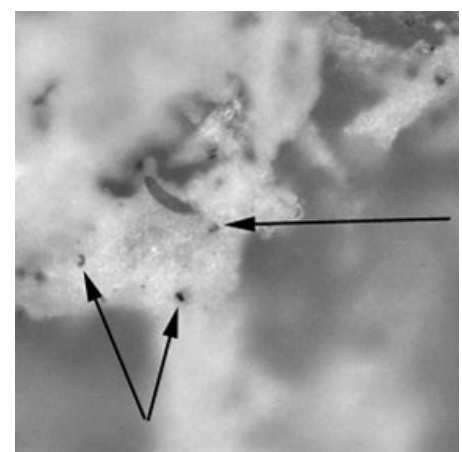

Figure 4. Lipid residue containing vivianite crystals on Artefact 2, DFX500 (Photograph: V. Francis).

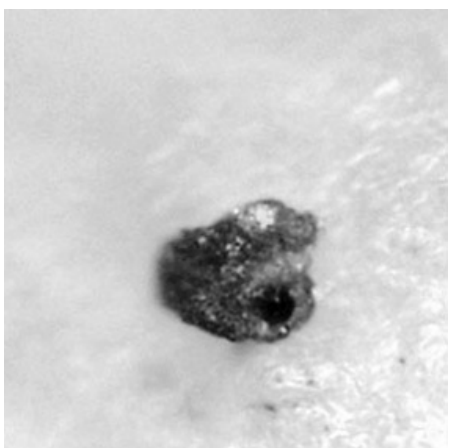

Figure 6. Blue vivianite crystal on surface of Artefact 1, DFX500 (Photograph: V. Francis).

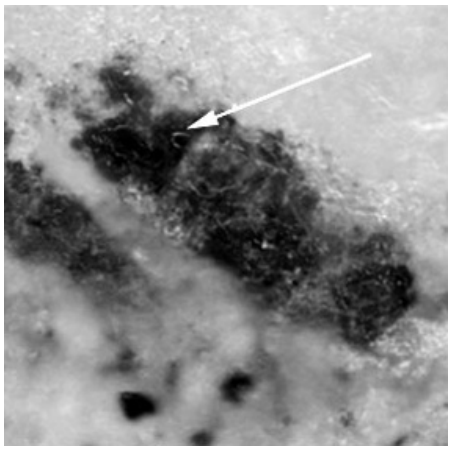

Figure 8. Blood residue on Artefact 20, DFX500. Arrow indicates a red blood cell (Photograph: V. Francis).

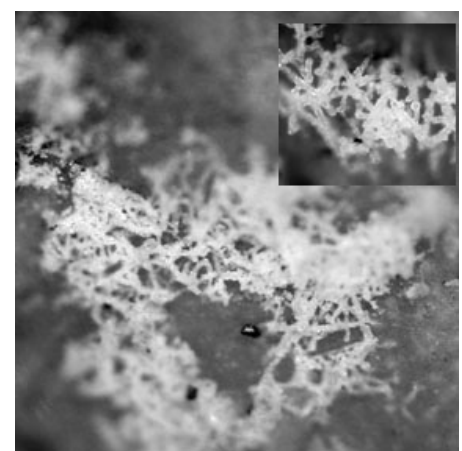

Figure 10. Patterned plant residue on Artefact 8, DFX100. Inset: BFXPOLX500 (Photograph: V. Francis). 


\section{Animal Residues}

Collagen fibres and sheets were observed on several artefacts and a blood residue, in which two red blood cells were embedded, was also detected (Figure 8). On Artefact 1 (which is awl-shaped) collagen fibres were identified around the tip (Figure 5), a pattern consistent with the artefact being used to pierce skin. Furthermore, skin piercing is the most commonly observed use for artefacts of this shape (e.g. Petrie 1904; Roth 1984[1897-1910]; Smyth 1878). A small keratinous fragment, probably a reptile scale, was also observed on one artefact (Figure 3).

Interestingly, bright blue crystalline residues were observed on five artefacts (Figure 6), one of which exhibited a variation in that these residues were dispersed through an opaque white residue (Figure 4). These blue flecks are possibly lipids that have crystallised with the mineral, vivianite, which is found in soil throughout Australia (Ralph 2001). Such a reaction has been observed frequently on ancient animal specimens in the Americas, the most famous example being an extinct bison known as 'Blue Babe' (Guthrie 1990). Such residues on these bone artefacts do not derive from modern handling (during excavation or processing) because the reactions involved with the lipid conversion require soil particles. Their presence on the Platypus Rockshelter artefacts is extremely unusual and warrants further investigation.

\section{Plant Residues}

A range of plant residues including starch, cellulose, resin (Figure 9), raphides and charcoal fragments was observed on several of the artefacts, from which two major groups were distinguished by their association. The first group was characterised by a distinctive white, crystalline residue (Figure 10) identified as floral in origin by its birefringent reaction to cross-polarised light. This residue was often associated with numerous small, round starch grains (1-2 $\mu \mathrm{m}$ diameter), rod-shaped pointed raphides, cellulose fibres, and discrete cell wall structures. This association was inferred as coming from the roots of Typha sp. (bulrush or cattail) on the basis of three significant factors: the size, shape and abundance of the starch grains; the presence, size and shape of the raphides; and, the characteristic structure of the white crystalline residue. Typha sp. is found throughout the world and is commonly used as a food source (Cribb and Cribb 1980; Isaacs 1987; Latz 1995; Symons and Symons 1994). Several ethnographers have observed Typha being exploited for food (generally during Spring-Summer due to new shoot growth) and the fibres were used for weaving throughout Australia (McBride 2000). More research should be conducted on the artefacts as well as on Indigenous uses of Typha sp. before more detailed statements can be made about the association noted in this study. However, because this residue was observed in abundance on 12 artefacts, these bone tools are inferred to have functioned in some way associated with the processing of Typha.

The second group of plant residue comprises a relatively clear vitreous residue that was observed on four artefacts. Bordered pits were observed embedded in two of these residues (Figure 7). Bordered pits are found in plant vascular systems and are used to control the transport of fluids to and from tissues. Their presence in the residue indicates traces of plant vascular fluids. In one case this residue appeared to be deposited over a fungal growth, perhaps the result of the artefact being manufactured, discarded, then re-used. However, further investigation is required before definitive statements about how these residues were deposited may be made.

Resin, while present on several artefacts, was not observed in sufficient quantities to provide information about hafting. Only Artefact 8 exhibited resin in quantity; it is a broken bone tip and was possibly used to slice bark from a tree (T. Loy, School of Social Science, University of Queensland, pers. comm., 2000).

\section{Ochre Residue}

Ochre was the most abundant inorganic residue detected in this assemblage. On two artefacts the distribution of orange-red ochre appeared to have been smeared into the surface some time after manufacture. This inference is based on the residue being embedded into various indentations characteristic of aged or degraded bone surfaces that were surrounded by well-polished surfaces. Ochre is commonly used in Indigenous Australian cultures for body and artefact decoration and it is often imbued with spiritual significance (Sagona 1994).

\section{Conclusions}

Although several different residue types were observed on these bone artefacts, more detailed investigation should be conducted before any decisive functional label is assigned to any of them. Nevertheless, at a coarse-grained level the results permit the interpretation that one artefact was probably used to process skin, several were used to process plant material and the other residues probably resulted from incidental touch-transfer contact. Artefact 1 appears to have had a similar function to that ethnographically described for skin processing. Unfortunately, while the ethnographic record may imply that bone artefacts were used to process plants, it contains insufficient detail to warrant similar analogous reasoning of the direct sort in respect of function. On evidence, these artefacts were possibly used to peel or cut Typha sp. but replicative 'middle range' research should be conducted to test this hypothesis.

This study complements Skelton's (1996) residue analysis of Platypus Rockshelter stone artefacts, especially since plant residues appear to predominate in both assemblages. It would be useful to undertake a detailed comparison of the results of both studies in order to ascertain whether or not the plant species are the same. Further investigation of the Typha sp. residues is also needed. In particular, as Typha sp. was known to have been exploited in Spring-Summer its presence may provide a seasonal indicator of site use and could thus be used in testing Lilley's (1978) seasonal model of the region's occupation. Finally, while the sample size in this study was too small to investigate chronological matters, it would be worthwhile to expand this investigation to examine possible chronological change in bone artefact manufacture and use in southeast Queensland and beyond.

In conclusion, this study demonstrates that nondestructive residue analysis can be undertaken on such fragile artefacts as bone points. Further residue analyses should be conducted on bone artefacts to enhance our knowledge of this undervalued component of Indigenous 
Australian material culture as well as other aspects of material culture that do not often survive in the archaeological record.

\section{Acknowledgements}

Thanks to Sean Ulm for his advice, support and feedback. I also thank A/Prof. Jay Hall and Dr Tom Loy for their advice and comments. A/Prof. Hall kindly provided access to the bone artefacts for this study. I am grateful to members of Tom's Group at the Archaeological Sciences Laboratory at the University of Queensland, especially Sue Nugent, Gail Robertson, Alison Crowther, Ken Dusza, Luke Kirkwood and Paul Kajewski. Tony Eales prepared Figure 1. This study was undertaken as a Bachelor of Arts (Honours) research project (Francis 2000) supervised by A/Prof. Hall and Dr Loy at the University of Queensland.

\section{References}

Angas, G.F. 1969 [1847] Savage Life and Scenes in Australia and New Zealand: Being an Artist's Impressions of Countries and People at the Antipodes. 2nd ed. Adelaide: Libraries Board of South Australia.

Beaton, J.M. 1977 Dangerous Harvest: Investigations in the Late Prehistoric Occupation of Upland South-East Central Queensland. Unpublished $\mathrm{PhD}$ thesis, Department of Prehistory, Research School of Pacific and Asian Studies, Australian National University, Canberra.

Bowdler, S. 1970 Bass Point: The Excavation of a South-East Australian Shell Midden Showing Cultural and Economic Change. Unpublished BA (Hons) thesis, Department of Anthropology, University of Sydney, Sydney.

Bowdler, S. 1979 Hunter Hill, Hunter Island. Unpublished PhD thesis, Department of Prehistory, Research School of Pacific and Asian Studies, Australian National University, Canberra.

Collins, D. 1910 An Account of the English Colony in New South Wales. Christchurch: Whitcombe \& Tombs.

Cribb, A.B. and J.W Cribb. 1980 Wild Food in Australia. Sydney: Collins.

Curr, E. 1883 Recollections of Squatting in Victoria. Melbourne: George Roberston.

Curr, E.M. 1886 The Australian Race: Its Origins, Languages, Customs, Place of Landing in Australia, and The Routes by which it Spread Itself Over That Continent. Melbourne: John Ferres, Government Printer.

Dawson, J. 1881 Australian Aborigines: The Language and Customs of Several Tribes of Aborigines in the Western District of Victoria, Australia. Melbourne: George Robertson.

Fisher Jr., J.W. 1995 Bone surface modifications in zooarchaeology. Journal of Archaeological Method and Theory 2:7-68.

Flanagan, R.J. 1888 The Aborigines of Australia. Sydney: E.F. Flanagan and George Robertson \& Co.

Flood, J. 1974 Pleistocene man at Clogg's Cave: His tool kit and environment. Mankind 9:175-188.

Flood, J. 1980 The Moth Hunters: Aboriginal Prehistory of the Australian Alps. Canberra: Australian Institute of Aboriginal Studies.

Flood, J. 1990 The Riches of Ancient Australia. St Lucia: University of Queensland Press.

Flood, J. 1995 Archaeology of the Dreamtime. Sydney: Angus \& Robertson.

Francis, V.C.M. 2000 What's the Point?: An Investigation of the Bone Artefacts from Platypus Rockshelter, Southeast Queensland. Unpublished BA (Hons) thesis, Department of Sociology, Anthropology and Archaeology, University of Queensland, Brisbane.
Guthrie, R.D. 1990 Frozen Fauna of the Mammoth Steppe: The Story of Blue Babe. Chicago: University of Chicago Press.

Hall, J. 1980 Archaeology at the University of Queensland: A brief outline. Australian Archaeology 10:79-85.

Hall, J., D.S Gillieson and P. Hiscock 1988 Platypus Rockshelter (KB:A70), S.E. Queensland: Stratigraphy, chronology and site formation. Queensland Archaeological Research 5:2541.

Hiscock, P. and J. Hall 1988 Technological change at Platypus Rockshelter (KB:A70) S.E. Queensland. Queensland Archaeological Research 5:63-89.

Isaacs, J. 1987 Bush Food: Aboriginal Food and Herbal Medicine. McMahons Point, NSW: Weldons.

Kenyon, A.S. 1912 Camping places of the Aborigines of southeast Australia. The Victorian Historical Magazine 2:97-110.

Lampert, R.J. 1971 Burrill Lake and Currarong: Coastal Sites in Southern New South Wales. Terra Australis 1. Canberra: Department of Prehistory, Research School of Pacific Studies, Australian National University.

Latz, P. 1995 Bushfires and Bushtucker: Aboriginal Plant Use in Central Australia. Alice Springs: IAD Press.

LeMoine, G. 1994 Use-wear on bone and antler tools from the Mackenzie Delta, Northwest Territories. American Antiquity 59:316-335.

Lilley, I.A. 1978 Prehistoric Subsistence and Settlement in the Subcoastal Zone of the Moreton Region, Southeast Queensland. Unpublished BA (Hons) thesis, Department of Anthropology and Sociology, University of Queensland, Brisbane.

Loy, T.H. 1993 The artefact as site: An example of the biomolecular analysis of organic residues on prehistoric tools. World Archaeology 25:44-63.

Loy, T.H. 1994 Analysis of the Artefacts of the Ice Man of Haslabjock: Microscopy and Residue Analysis. Unpublished report to Institute of Alpine Research, University of Innsbruck.

Loy, T.H. 1999 Molecular Archaeology. Unpublished report to Department of Anthropology and Sociology and the Centre of Molecular and Cellular Biology, University of Queensland, Brisbane.

Loy, T.H. in prep. Methods in the Analysis of Archaeological Tool-Use Residues: Proteins and Starch.

Loy, T.H., M. Spriggs and S. Wickler 1992 Direct evidence for human use of plants 28,000 years ago: Starch residues on stone artefacts from the northern Solomon Islands. Antiquity 66:898-912.

Massola, A. 1957 Australian fish hooks and their distribution. Memoirs of the National Museum Melbourne 22:1-17.

McBride. S. 2000 Australian Aboriginal Resource Selection: Reasons and Implications. Unpublished BA (Hons) thesis, Department of Sociology, Anthropology and Archaeology, University of Queensland, Brisbane.

McBryde, I. 1974 Aboriginal Prehistory in New England. Sydney: University of Sydney Press.

McCarthy, F.D. 1976 Australian Aboriginal Stone Implements. Sydney: The Australian Museum Trust.

Mitchell, S.R. 1949 Stone-Age Craftsmen: Stone Tools and Camping Places of the Australian Aborigines. Melbourne: Tait Book Co.

Novello, M. 1989 A Taphonomic Analysis of the Faunal Remains from Platypus Rockshelter (KB:A70), Southeast Queensland. Unpublished BA (Hons) thesis, Department of Anthropology and Sociology, University of Queensland, Brisbane. 
Olsen, S.L. 1988 The identification of stone and metal tool marks on bone artefacts. In S.L. Olsen (ed.), Scanning Electron Microscopy in Archaeology, pp.337-363. BAR International Series 452. Oxford: Tempvs Reparatvm.

Petrie, C.C. 1904 Tom Petrie's Reminiscences of Early Queensland. Brisbane: Watson, Ferguson \& Co.

Pretty, G.L. 1977 The cultural chronology of the Roonka Flat. In R.V.S Wright (ed.), Stone Tools as Cultural Markers: Change, Evolution and Complexity, pp.288-331. Canberra: Australian Institute of Aboriginal Studies.

$\mathrm{R}$ a $1 \mathrm{p} \mathrm{h}, \quad \mathrm{J} . \quad 2001 \quad V i v i a n i t e$. http://www.mindat.org/show.php?id=4194\&ld=1\&pho=

Roth, W.E. 1897 Ethnological Studies among the North-WestCentral Queensland Aborigines. Brisbane: Government Printer.

Roth, W.E. 1984 [1897-1910] The Queensland Aborigines. Fascimile edition. Victoria Park: Hesperian Press.

Sagona, A.G. 1994 The quest for red gold. In A.G. Sagona (ed.), Bruising the Red Earth: Ochre Mining and Ritual in Aboriginal Australia, pp.8-38. Melbourne: Melbourne University Press.

Skelton, S.M. 1996 Starch Trek, The Search for Residue: An Examination of the Relationship between Technological Change and Resource Exploitation at Platypus Rockshelter (KB:A70), Southeast Queensland. Unpublished PGDipArts (Anthropology) thesis, Department of Anthropology and Sociology, University of Queensland, Brisbane.

Smyth, R.B. 1878 The Aborigines of Victoria and Other Parts of Australia and Tasmania. Melbourne: George Robertson.

Spencer, B. 1904 The Northern Tribes of Central Australia. Edinburgh: R. \& R. Clarke.
Spencer, B. 1915 Guide to the Australian Ethnological Collection Exhibited in the National Museum of Victoria. Melbourne: D.W. Paterson.

Symons, P. and S. Symons 1994 Bush Heritage: An Introduction to the History of Plant and Animal Use by Aboriginal People and Colonists in the Brisbane and Sunshine Coast Areas. Nambour: P. \& S. Symons.

Thomson, D. 1936 Notes on some bone and bone implements from north Queensland. Journal of the Royal Anthropological Institute of Great Britain and Ireland 66:71-74.

Ulm, S. and J. Hall 1996 Radiocarbon and cultural chronologies in southeast Queensland prehistory. In S. Ulm, I. Lilley and A. Ross (eds), Australian Archaeology '95: Proceedings of the 1995 Australian Archaeological Association Annual Conference, pp.45-62. Tempus 6. St Lucia: Anthropology Museum, University of Queensland.

Webb, C. 1987 Use-Wear on Bone Tools: An Experimental Program and Three Case-studies from South-East Australia. Unpublished BA (Hons) thesis, La Trobe University, Melbourne.

Webb, C. and J. Allen 1990 A functional analysis of Pleistocene bone tools from two sites in southwest Tasmania. Archaeology in Oceania 25:75-78.

Worsnop, T. 1897 The Prehistoric Arts, Manufactures, Works, Weapons, etc., of the Aborigines of Australia. Adelaide: Government Printer. 